$56: 1174$

\author{
$<$ 原 著 $>$ \\ 原発性胆汁性肝硬変ならびに各種胆汁うっ滞における \\ 肝細胞内銅およびオルセイン陽性顆粒状 \\ 物質の形態学的研究
}

仲紘嗣*

\begin{abstract}
要 旨: 原発性胆汁性肝硬変（以下 PBC）の肝病変進展における肝紐胞内銅沈着の役割括よび オルセイン染色の診断的有用性を検討する目的で, PBC ならびに各種胆汁らっ滞に和ける肝組 織標本の銅染色特よびオルセイン染色を和こなった、銅染色拉よびオルセイン染色の染色性の比 較では，銅染色陽性例はいずれるオルセイン染色陽性で解離例はなかったが，オルセイン染色の 方が量的に多く観察された. 肝細胞内の銅沈着はPBC で20例中16例，その他の胆汁うっ滞13例 中 6 例，慢性肝炎・肝硬变 42 例中 1 例涊認められた。 PBC での肝細胞内銅沈着は病期の進展と ともに小葉周辺部の核周囲に増加してみられ，また黄疸例では全例に無黄疸例ではビリルビン以 外の胆汁成分のうっ滞を来たした症例に観察された．以上ょり PBC に抢ける肝細胞内銅沈着は ビリルビン以外の胆汁成分のらっ滞を来たす早期から始をり，肝病変進展への重要な一因子で あることが示唆され，早期治療が必要と思われた。 また肝細胞内オルセイン陽性顆粒状物質は PBC 以外の胆汁らっ滞でも認められ，PBC に特異的所見とみなすことはできなかった。
\end{abstract}

索引用語： 原発性胆汁性肝硬変 銅沈着（肝細胞内一）オルセイン陽性顆粒状物質

\section{I.はじめに}

原発性胆汗性肝硬变 (primary biliary cirrhosis, 以下 PBC) は MacMahon ${ }^{12}$, Ahrens $5^{2)}$ 亿り臨床病理学的 な一疾患単位として確立されたが，今日な和 PBC の病 因や病態に関して不明な点が多い"゙．たとえば，一次的 障害部位と考えられている中等大小葉間胆管ないし隔 壁胆管に扣ける慢性非化膿珄破壊性胆管炎4) の発生機序 や，二次的障害と思われる肝病変の進展（線維化抢よび 硬変化）の機序などがあげられる.肝病変進展の一因子 として，肝細胞内の銅沈着が Hunt $5^{5)}$ の報告以来議論

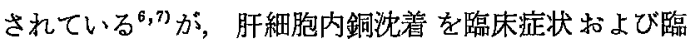

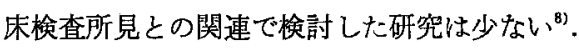

近年, オルセイン染色にて染色される肝細胞内顆粒状 物質が PBC と chronic active hepatitis (CAH) との鑑 別診断に有用でするとされているが9)，PBC 以外の長期

\footnotetext{
* 新鼬大学医学部第 3 内科 (主任 : 市田文弘教授)
} <受付日55年 3 月 10 日 $>$
胆汁らっ滞でも同様の染色例がみられ PBC に特異的とはい之ないようである. 一力，銅染色 とオルセイン染色に打梳解離も報告されて特り ${ }^{10,13)}$, オルセイン染色陽性顆粒状物質の同定や解離例の検討も 残された問題である.

ここでは PBC の肝病変進展における肝細胞内銅沈着 の役割，オルセイン染色の診断的有用性などを検討する 目的で, PBC ならびに各種胆汁うっ滞における肝組織 標本について銅染色括よびオルセイン染色を抗こない， その染色性・染色部位を比較検討し，銅沈着之胆汁らっ 滞の期間・程度 - 治療との関連や銅沈着の肝細胞内局在 について検討を加壳た.

\section{II. 対象と方法}

対象患者㧊よび肝組織標本数は PBC 20例28標本。 PBC 以外の各種胆汁万っ滞13例 19 標本で, 刘照例は42 例42標本であった. 各種胆汁うっ滞の内わけは, 慢性薬 剤起因性肝内胆汁 万。滞 4 例10標本, 若年性小葉間胆管 形成不全 2 例 2 標本 (以下いずれも1 例につき1標本), 
Table 1. Materials

\begin{tabular}{lc}
\hline Cholestatic Liver Disease & No. of Cases \\
\hline Primary Biliary Cirrhosis & 20 \\
Other Chronic Intrahepatic Cholestasis & 6 \\
Chronic Drug-induced Intrahepatic & \\
$\quad$ Cholestasis & $(4)$ \\
Hypoplasia of the Interlobular Bile & \\
$\quad$ Ducts in Juvenile & $(2)$ \\
Extrahepatic Obstructive Jaundice & 5 \\
Acute Intrahepatic Cholestasis & 2 \\
Controls & 42 \\
Chronic Hepatitis & $(18)$ \\
Liver Cirrhosis & $(24)$ \\
\hline Total & 75 \\
\hline
\end{tabular}

肝外閉塞性黄㾞 5 例，急性肝内胆汁 $っ っ$ 滞 2 例であっ た. 対照例の内わ计は，黄瘟のない慢性肝炎18例，肝硬 変24例であった (Table 1).
PBC の診断は, (1) 肝組織像が chronic nonsuppurative destructive cholangitis (CNSDC) の所見を示する $の^{15)}$ ，(2) 系粒体抗体 (mitochondrial antibody, AMA) が陽性を示し，組織学的に CNSDC の所見は認めない が，PBC に矛盾しない(compatible) 組織像を示すも の ${ }^{16)}$ とした. Table 2 K PBC 患者20例の臨床的 - 生化 学的・免疫学的・組織学的特徵を要約 した，血清 HBs 抗原は PBC 診断時には全例陰性であったが，経過中治 療の目的で輸血を施行した 2 例に一過性陽性を示した. 一方, HBs 抗体は 1 例 (Case 20) のみ陽性であった。 PBC の病期分類は Scheuer の分類に従った ${ }^{15)}$. その内 わけは，I期が 8 例10標本，II期が 6 例 7 標本(このう ち 1 例 1 標本は第 1 回目生检時 I 期の所見を示したが, 第 2 回目生検時 II 期に進展した症例を含んでいる)，III 期が 4 例 6 標本，IV期が 3 例 5 標本 である. これらの 症例中, asymptomatic PBC は 4 例 5 標本 (Case 6, 7, 19，20) である. Case 20は，外科的切除標本による組 織学的検討では肝硬变像を呈したが, 胆汁性肝硬変の特

Table 2. Clinical, biochemical and histological features of patients with primary biliary cirrhosis

\begin{tabular}{|c|c|c|c|c|c|c|}
\hline $\begin{array}{l}\text { Case } \\
\text { No. }\end{array}$ & $\begin{array}{l}\text { Age at } \\
\text { Onset }\end{array}$ & Sex & Main Clinical Sign & $\underset{(\mathrm{mg} / \mathrm{d} l)}{\operatorname{IgM}}$ & $\begin{array}{l}\text { AMA* } \\
(45)^{* *}\end{array}$ & $\begin{array}{l}\text { Liver Biopsy } \\
\text { Findings }\end{array}$ \\
\hline 1 & 45 & $\mathbf{F}$ & Pruritus & 450 & + & CNSDC \\
\hline 2 & 58 & $\mathbf{M}$ & Pruritus & 364 & + & CNSDC \\
\hline 3 & 61. & $\mathrm{~F}$ & Jaundice & 476 & + & CNSDC \\
\hline 4 & 44 & F & Jaundice & 366 & + & Hepatic Fibrosis \\
\hline 5 & 56 & $\mathrm{~F}$ & Hematemesis & 712 & + & CNSDC \\
\hline 6 & 52 & $\mathbf{M}$ & asymptomatic & 142 & + & CNSDC \\
\hline 7 & 58 & $\mathbf{F}$ & asymptomatic & 199 & + & CNSDC \\
\hline 8 & 51 & $\mathrm{~F}$ & Jaundice & 257 & $-(\mathrm{PHA}+)$ & CNSDC, LC, M-body \\
\hline 9 & 33 & F & Jaundice & 1218 & $-($ PHA +$)$ & CNSDC \\
\hline 10 & 52 & $\mathbf{F}$ & Pruritus & 316 & + & CNSDC \\
\hline 11 & 30 & $\mathbf{F}$ & Pruritus & 540 & + & CNSDC, Granuloma \\
\hline 12 & 46 & F & Pruritus & 474 & + & CNSDC \\
\hline 13 & 51 & $\mathrm{~F}$ & Pruritus & 526 & + & CNSDC, Granuloma \\
\hline 14 & 62 & $\mathrm{~F}$ & Pruritus & 716 & + & CNSDC \\
\hline 15 & 53 & $\mathrm{~F}$ & Jaundice & 672 & + & CNSDC \\
\hline 16 & 52 & $\mathbf{M}$ & Jaundice & 307 & - & CNSDC, Granuloma \\
\hline 17 & 44 & F & Arthritis & 377 & + & CNSDC \\
\hline 18 & 64 & $\mathbf{M}$ & Pruritus & 738 & + & Compatible PBC \\
\hline 19 & 69 & $\mathrm{~F}$ & asymptomatic & 450 & + & CNSDC \\
\hline 20 & 78 & $\mathrm{~F}$ & asymptomatic & 780 & + & CNSDC, LC, Gránuloma \\
\hline
\end{tabular}

CNSDC : Chronic Non-suppurative Destructive Cholangitis.

M-body : Mallory's body LC : Liver Cirrhosis.

* Immunofluorescence Technique. ** Reference No. 
$58: 1176$

徵はなく CNSDC を伴った乙型肝硬変であり，IgM の 高值・AMA の高力価陽性を示し, また無症状, 無黄疸 で, 血清アルカリホスファターゼ (Al-p) および総コレ ステロール (T-chol) 值が正常範囲にある，いわゆる overlapping syndrome (Popper) ${ }^{17}$ に該当する例で, PBC としては I 期に分類した. 他の 3 例は無症状, 無黄㾝 で血清 Al-p および T-chol 值が汪涪正常であり, AMA は陽性でかつ組織学的に CNSDCを認めたI期 (Case 19)，II期 (Case 6，7) の PBC であった. PBC の肝 組織標本数は needle biopsy 10 標本, surgical wedge biopsy 12 標本, autopsy 4 標本, necropsy 2 標本であっ た.

僈性薬剤起因性肝内胆汁万っ滞 ${ }^{18,199}$ はいずれる顕性黄 疸（血清総ビリルビン 值 $2 \mathrm{mg} / \mathrm{d} l$ 以上）が 1 年以上持続 した症例で，起因薬㓮はサルファ剤了例，むむしドリン ク剂 1 例であった．若年性小葉閒胆管形成不全 ${ }^{20)}$ は市田 らが提唱した疾患であり，16歳・11歳の兄妹例で胆汁う っ漁期間がそれぞれ 3 年 8 力月・ 4 年 5 力月と長期にわ たり，食道静脈瘤破裂により死亡した剖検例である.

肝外閉塞性黄疸は総胆管結石にて黄疸が 1 年 1 力月持 続した 1 例と, 膵頭部癌による閉塞性黄㾝が 8 カ月持続 した 1 例, 括よび脺頭部癌・胆のら癌・胃癌のそれぞれ 旰門部転移による閉塞性黄疸が 4 週以内の 3 例であっ た.

急性肝内胆汁万っ滞の 2 例はいずれも薬成によるもの でそれぞれ1力月，4 力月間黄疾が持続した.

対照例は慢性肝炎が18例で，犬山分類では活動性が11 例・非活動性が 7 例であった. 肝硬変は24例で, HBs抗 原または抗体陽性例が 4 例，アルコール常飲者14例，そ の他 6 例であった. 以上の75例の $\alpha_{1}$ グロブリン值は全 て正常範用内にあった.

肝組織の光顕的・電頙的観察は以下の方法によった。

1. 銅染色 (全標本に施行)

(1) パラジィルアミノベンチリデンロダニン (p-dimethylamino-benzylidene-rhodanine) 法 ${ }^{21)}$

(2) ルベアン水素酸法 (rubeanhydric acid) 法 ${ }^{21}$

2. オルセイン (orcein) 染色, 志方法 ${ }^{22}$ （全標本に 施行)

3. 肝組織内の銅染色およびオルセイン染色の染色程 度に関する分類

(1) 標本全体の $80 \%$ 以上の小葉に高度に染色されるも のを (H) (Fig. 1).

(2) 同様に $80 \%$ 以上の小葉に中等度ないし軽度染色さ

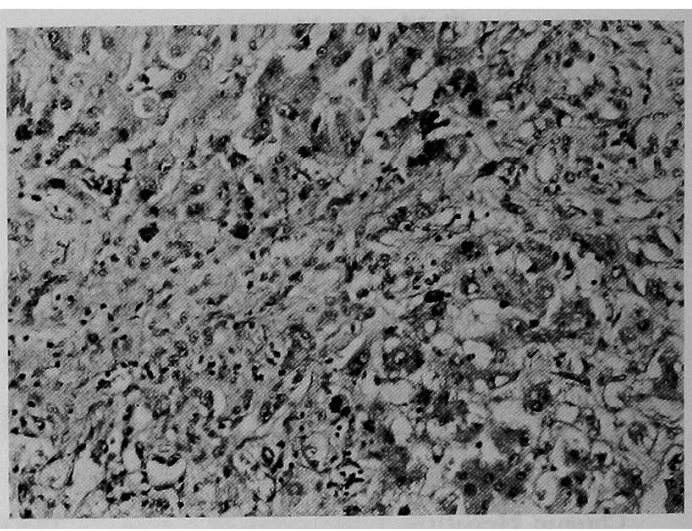

Fig. 1 Orcein positive granular substances in a periportal area, grade (H), (orcein stain after oxidation with potassium permanganate, $\times 150$ ).

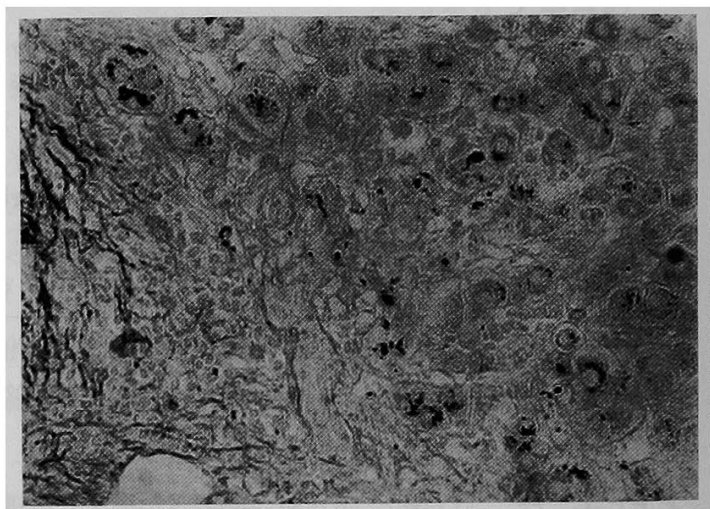

Fig. 2 Orcein positive granular substances in a periportal area, grade $(+)$, (orcein stain after oxidation with potassium permanganate, $\times 300)$.

れるものを(十) (Fig. 2).

(3) $20 \%$ 以下の小葉に限局して軽度に染色されるすの を(士)とした。

な特，小葉の20〜80\%に分布する症例は見当たらなか った。

また, $\mathrm{PBC}$ 症例の肝細胞内の銅の局在を検討するた め, 各標本の小葉周辺部と中間部からそれぞれ銅染色陽 珄細胞10コずつ選び, 核周囲に染色されるむの (perinuclear type, Fig. 3) と，細胞質全体に染色されるるの (cytoplasmic type, Fig. 4) とに分類し，各病期毎にそ の百分率を算出した。

4. PBC 症例の一部に透過電䫓による 銅染色抏よび オルセイン染色陽性顆粒状物質の観察を叔こなった。 ま た，銅の肝細胞障害性を検討する目的で，門脈域周辺部 


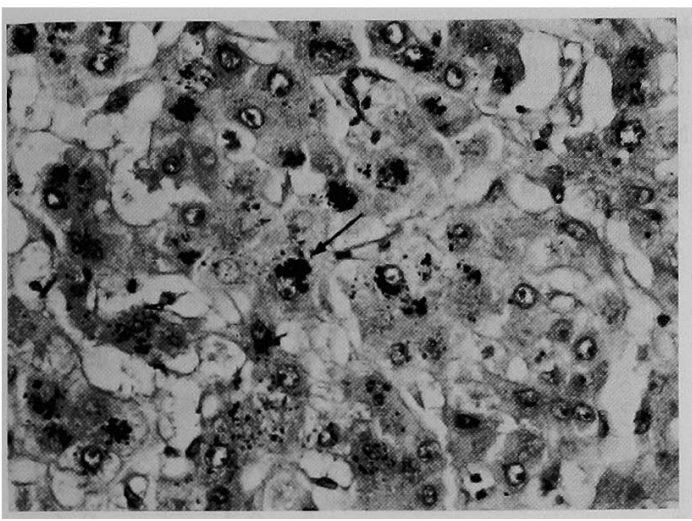

Fig. 3 Localization of copper-deposits in hepatocytes: perinuclear type (arrow), (orcein stain after oxidation with potassium permanganate, $\times 300$ ).

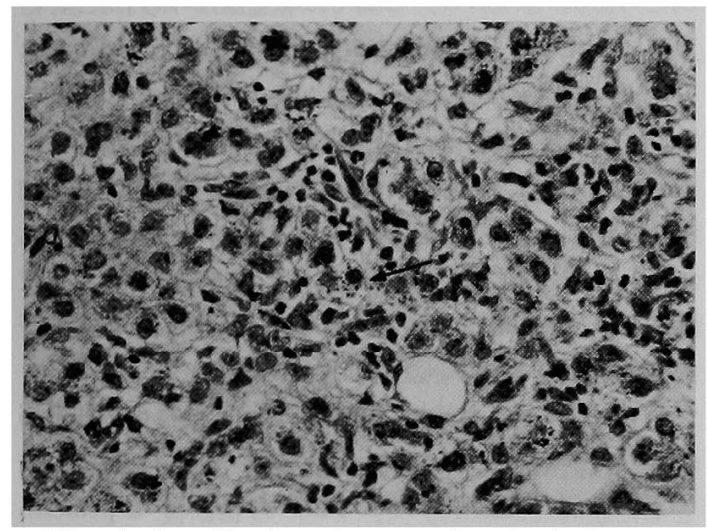

Fig. 4 Localization of copper-deposits in hepatocytes: cytoplasmic type (arrow), (orcein stain after oxidation with potassium permanganate, $\times 300$ ).

の肝細胞と中間部〜中心部の肝細胞に分けて肝細胞内小 器官の電顕的観察を执こなった。

(1) 生検または剖検材料を $2.5 \%$ グルタールアルデ八 イド・ $2 \%$ オミウム酸で二重固定後, 脱水, 包埋し た.ついで $1 \mu$ の厚切り標本を作製 $\mathrm{L}$, トルイジンブル 一 (toluidine blue) 染色を施行して光影的観察をおこな った.

(2) 電顕材料の超薄切片を醋酸鉛による単染色にて日 立電子顕微鏡 (HS- 9 型) で観察し写真撮影した。

肝組蟣標本の銅染色およびオルセイン染色陽性率に関 する統計処理は $\mathbf{x}^{2}$-テスト（Yeats の修正）を用いた。

\section{III. 成 續}

1. 銅染色およびオルセイン染色における染色性・染 色部位の比較検討

(1) 染色性の比較

同一症例に和ける銅染色（ロダニン法・ルベアン水素 酸法) およびオルセイン染色の染色性の比較では，銅染 色陽性例はいずれもオルセイン染色陽性で，これらの3 法での解離例はみられなかった. しかし，量的にはオ ルセイン染色の方が銅染色よりる多く観察された（Fig. 5). またルベアン水素酸法は色調が暗緑色のため, 弱拡 大での鏡検はやや困難を感じた.

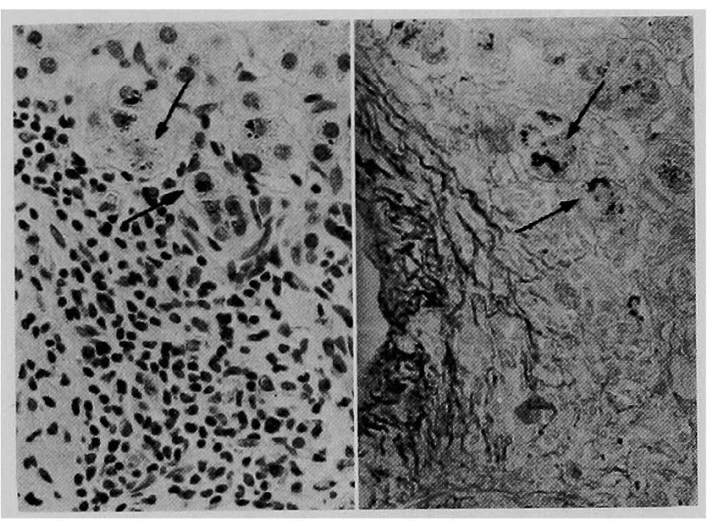

Fig. 5 Copper-deposits and orcein positive granular substances are seen in the same hepatocytes (arrows). (left: rhodanine stain, $\times 300$; right: orcein stain after oxidation with potassium permanganate, $\times 300$ ).

\section{(2) 染色部位の比较 (Fig. 5)}

全ての資料について厚さ $4 \mu$ の 3 枚連続切片を作製 し，それぞれに 3 法の染色を施行し，染色部位を比較し た. 3 法とも同一小葉内の主として小葉周辺部に，また 多くは同一細胞内の核周囲に染色陽性像が顆粒状に観祭 された. PBCに招ける肝組織内銅の局在については後 に詳細に記載する.

2. PBC ならびに各種胆汁うっ滞における銅染色お よびオルセイン染色阳性率 (Table 3)

全症例の 銅染色およびオルセイン染绝陽性率をみる と，PBC では20例中16例 $80 \%$ (28標本中23標本 $82.1 \%$ ), PBC 以外の胆汁う。滞全体では13例中 6 例 $46.1 \%$ (19 標本中 9 標本 $47.3 \%$ ), 対照群は42例中 1 例 $2.4 \%$ であっ た. 対照群中銅染色陽性の 1 例はいわゆる cryptogenic cirrhosisであった，銅染色牤よびオルセイン染色陽性率 
Table 3. Incidence of cases with positive rubeanic acid and rhodanine stain in primary biliary cirrhosis and other liver diseases

\begin{tabular}{|c|c|c|c|c|}
\hline Cholestatic Liver Diseases & No. Cases & $\begin{array}{l}\text { No. Positive for } \\
\text { Copper Stain }\end{array}$ & \multicolumn{2}{|c|}{$\begin{array}{l}\% \text { Positive for } \\
\text { Copper Stain }\end{array}$} \\
\hline Primary Biliary Cirrhosis & 20 & 16 & 80.0 & 80.0 \\
\hline \multicolumn{5}{|l|}{ Other Chronic Intrahepatic Cholestasis } \\
\hline Chronic Drug-induced Intrahepatic Cholestasis & 4 & 3 & \multirow{2}{*}{83.3} & \multirow{4}{*}{46.1} \\
\hline Hypoplasia of the Interlobular Bile Ducts in Juvenile & 2 & 2 & & \\
\hline Extrahepatic Obstructive Jaundice & 5 & 1 & 20.0 & \\
\hline Acute Intrahepatic Cholestasis & 2 & 0 & 0 & \\
\hline \multicolumn{5}{|l|}{ Controls } \\
\hline Chronic Hepatitis & 18 & 0 & \multirow{2}{*}{2.4} & \multirow{2}{*}{2.4} \\
\hline Liver Cirrhosis & 24 & 1 & & \\
\hline
\end{tabular}

Table 4. Copper and orcein-positive granular substances in hepatocytes of patients with primary biliary cirthosis

\begin{tabular}{|c|c|c|c|c|c|}
\hline $\begin{array}{l}\text { Case } \\
\text { No. }\end{array}$ & Stage & $\begin{array}{c}\text { Biopsy } \\
\text { No. }\end{array}$ & Rhodanine & $\begin{array}{c}\text { Rubeanic } \\
\text { Acid }\end{array}$ & Orcein \\
\hline 10 & I & $\begin{array}{l}1 \\
2 \\
3\end{array}$ & $\begin{array}{l}+ \\
+ \\
+\end{array}$ & $\begin{array}{l}+ \\
+ \\
+\end{array}$ & $\begin{array}{l}+ \\
+ \\
+\end{array}$ \\
\hline 11 & I & & + & + & + \\
\hline 13 & I & & \pm & \pm & \pm \\
\hline 17 & I & & \pm & \pm & \pm \\
\hline 18 & I & & + & + & + \\
\hline 19 & I & & - & - & - \\
\hline 20 & I & & - & - & - \\
\hline 15 & I & 1 & + & + & + \\
\hline & II & $2 *$ & + & + & + \\
\hline 5 & II & & + & + & + \\
\hline 6 & II & & - & - & - \\
\hline 7 & II & 1 & - & - & - \\
\hline 9 & II & 2 & $\vec{t}$ & $\overrightarrow{+}$ & + \\
\hline 14 & II & & + & + & + \\
\hline 3 & III & & H & H & H \\
\hline 4 & III & $\begin{array}{l}1 \\
2\end{array}$ & + & + & $\stackrel{+}{H}$ \\
\hline 12 & III & $\begin{array}{l}1 \\
2\end{array}$ & + & $\begin{array}{l}t \\
t\end{array}$ & + \\
\hline 16 & III & & $H$ & $H$ & $H$ \\
\hline 1 & IV & & H & H & $H$ \\
\hline 2 & IV & & + & + & + \\
\hline 8 & IV & $\begin{array}{l}1 \\
2 \\
3\end{array}$ & $\begin{array}{l}+ \\
+ \\
+\end{array}$ & $\begin{array}{l}+ \\
+ \\
+\end{array}$ & $\begin{array}{l}+ \\
+ \\
+\end{array}$ \\
\hline
\end{tabular}

* treated with D-penicillamine
は PBC とその他の胆汁らっ滞例の間では有意差はみら れす。， $\mathrm{PBC}$ と対照例 $(\mathrm{p}<0.01)$ ，その他の胆汁うっ滞 例之対照例 $(\mathrm{p}<0.01)$ の間では有意差がみられた。

3. PBC における铜染色およびオルセイン染色結果 PBC 全症例の銅染色拉よびオルセイン染色結果を Scheuer の病期分類によって区分し示した (Table 4). 寸なわち I ・ II 期の13例17標本の染色結果は陰性が 4 例 5 標本，（土）が 2 例 2 標本，（十）が 7 例10標本であ った. 一方，進行した II・IV期の 7 例11標本ではすべて 陽性で，（十）が 2 例 6 標本，（H）が5 例 5 標本と肝 病変の進展とともに銅沈着の程度が増強した。

つぎに D-penicillamine 使用前後の肝組織内銅沈着の 推移をみた 1 症例を呈示する，黄疸・皮盧痋㾟感を主訴 とした症例 (Case 15) で， PBC の診断後 D-penicillamine を維持量として 1 日 $800 \mathrm{mg} ， 3.5$ 月間の治療を おこなった．使用前の組織像はＩ期であったが，使用後 では細胆管増生，小葉周辺性胆汁うっ滞が諗められ I期 に進展していた. 肝組織標本の銅染色では, D-penicillamine 使用前後とも(十) であったが，使用後でやや 減少傾向（中等度軽度）がみられた，血清総ビリルビ ン，Al-p 值は使用中さしろ增加した．尿中への銅の排 泄は D-penicillamine 投与により著しく増加したが，血 清銅濃度は不変であった。 また免疫グロブリン中 IgM の減少がみられたが，糸粒体抗体の力価は不変であっ た.

\section{PBC における肝組織内銅の局在について}

銅染色陽性を示した PBC 16例の肝組織内銅の局在 を，標本全体の分布 - 小葉内での分布 - 肝細胞内の分布 の3つに分けて検討した. 


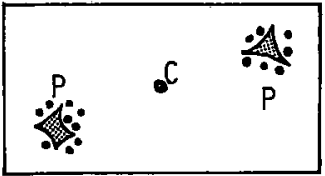

11 cases $(68.8 \%)$ periportal type

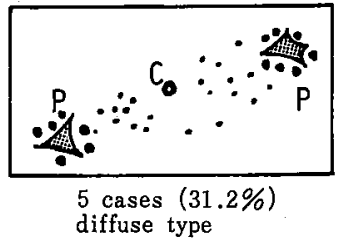

Fig. 6 Localization of copper-deposits in hepatocytes of patients with Primary Biliary cirrhosis

\section{(1) 標本全体の分布}

各標本中， $80 \%$ 以上小小葉にびまん性に分布していた

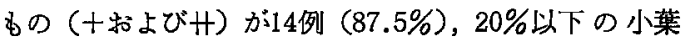
に限局していたすの（士）が2例（12.5\%）であった。 この 2 例はともにI期の PBC であった。

(2) 小葉内での分布 (Fig. 6)

小葉周辺部のみに限局していたものが11例 (68.8\%)， 少量であるが小葉全体に分布していたものが5例（31.2 \%)であった. この5例は各期に分散して和り，病期と の関連は認められなかった。

(3) 肝細胞内の分布 (Fig. 7)

銅染色陽性顆粒を小葉周辺部の肝細胞（16例）と中間 部〜中心部の肝細胞（5 例）に分けて，それそれれ核周 回型 (perinuclear type) と細胞質型 (cytoplasmic type) に分類し，百分率で示した. I ・ II 期の症例で小葉周辺 部の核周囲型のものは61.8\%であったが，III・IV期へと 進展すると核周囲型のるのが91.4\%で，肝細胞 1 ケあた りの銅沈着程度も増強していた.一方，小葉全体に分布 していたもので小葉中間部ないし中心部のものは病期が 進展しても銅の肝細胞内局在の型には変動がなかった.

5. PBCにおける肝組織内銅沈着と胆汁うっ滞の期 間・程度との関連について
PBC 症例の肝組織内銅沈着の有無を顕性黄誼例（血 清総ビリルビン值 $2 \mathrm{mg} / \mathrm{d} l$ 以上）と無黄㾝例に分けて険 討した.

(1) 影性黄疸例 (Fig. 8)

影性黄疸例では，胆汁らっ滯の期間が 1 年以内の 4 例 6 標本を含めて全例に，病期・胆汁うっ帯の期間・程度 と関連なく銅沈着が観察された。これらの黄疸例の中 で，肝組織内の銅沈着の時期を考える上で興味ある症例 が $2 ， 3$ みられた，Case 11 は I期の症例で軽度の黄疸

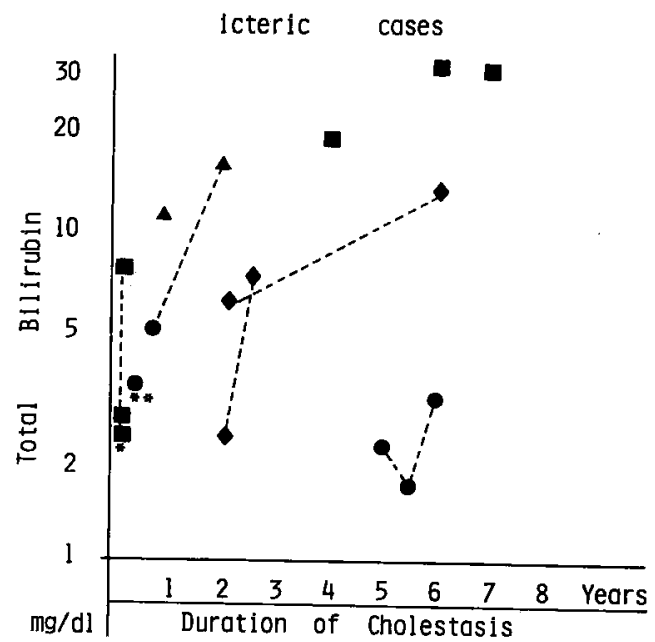

Fig. 8 Relationship between duration of cholestasis and copper-deposits in hepatocytes of patients with primary biliary cirrhosis.

copper-deposits: positive (filled symbols): dotted lines indicate the same patients. sheuer's classification: stage I $(\bullet)$, II $(\Delta), \mathbb{I I}(\bullet), \mathbb{I V}(\boldsymbol{\square})$. $*$ (case 8$) * *($ case 11$)$

\begin{tabular}{|c|c|c|c|c|}
\hline Stoge & \multicolumn{2}{|c|}{ Stage I, II } & \multicolumn{2}{|c|}{ Stage III, IV } \\
\hline $\begin{array}{l}\text { Locolization of } \\
\text { Copper in Hepatocytes }\end{array}$ & $\begin{array}{l}\text { perinucleor } \\
\text { type }\end{array}$ & $\begin{array}{l}\text { cytoplasml } \\
\text { type } \\
\end{array}$ & $\begin{array}{l}\text { perinuclear } \\
\text { type }\end{array}$ & \begin{tabular}{|l|}
$\begin{array}{c}\text { Cytoplasmic } \\
\text { type }\end{array}$ \\
\end{tabular} \\
\hline $\begin{array}{l}\text { Localization of } \\
\text { Copper in Liver } \\
\text { Lobules }\end{array}$ & & & & \\
\hline $\begin{array}{l}\text { periportal } \\
\text { areos } \\
16 \text { cases }\end{array}$ & $61.8 \%$ & $38.2 \%$ & $91.4 \%$ & $8.6 \%$ \\
\hline $\begin{array}{l}\text { mid-zonal and } \\
\text { central areas } \\
5 \text { cases }\end{array}$ & $36.7 \%$ & $63.3 \%$ & $40.0 \%$ & $60.0 \%$ \\
\hline
\end{tabular}

Fig. 7 Localization of copper-deposits in hepatocytes of patients with primary biliary cirrhosis 


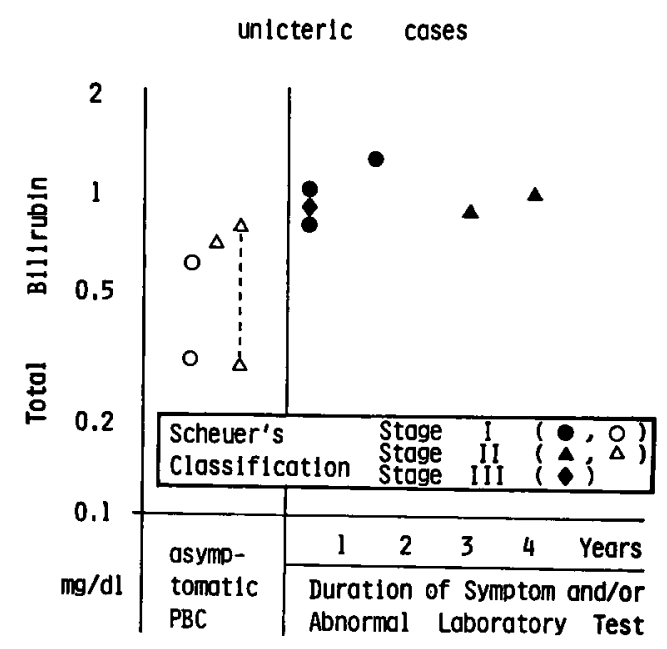

Fig. 9 Relationship between duration of symptom and/or abnormal laboratory test and copper-deposits in hepatocytes of patients with primary biliary cirrhosis.

copper-deposits: positive (filled symbols), negative (open symbols). dotted line indicates the same patient.

を呈し，胆汁うっ滞の期間が 4 カ月と短かいにもかかわ らず，銅沈着がみられた。 また Case 8 は全く無症状で 経過していたと思われるIV期の症例で，突然発熱と黄㾝 を呈し発症し，発症から 1 カ月の経過で死亡した.この 症例では高度の銅沈着が観察された。これの症例では 黄疸を呈する前から銅沈着を来たしたすのと思われた。

(2) 無黄疸例 (Fig. 9, Table 5)

無黄疸例の肝組織内銅沈着の有無を Fig. 9 に，たた 銅沈着の有無と臨床症状や臨床検查成績との対比を Table 5 に示した. asymptomatic PBC の 4 侧 5 標本で はいずれる銅沈着を認めなかった。これらの症例の血清 Al-p および T-chol 値はほぼ正常範囲であった，血清 総胆汁酸值は 2 例に㭘查しているがいずれる正常筙围で あった. 一方 symptomatic PBC の6 例はいずれる銅沈 着がみられた。 6 例中 3 例は皮痛瘦感が 2 カ月から 3 年持結して扣り，2 例は高コレステロール血症がそれぞ れ 1 力月・4年続いていた。. またこれらの6例とす20 $\mathrm{K}-\mathrm{A}$ 単位以上の血清 Al-p の高值が 1 カ月から 4 年間持 続していた４例に血清総胆汁酸を測定したが，いずれ も前值または食飼負荷後の高値を示した. 以上の結果よ り，無黄疸例の PBC ではビリルビン以外の胆汁成分の らっ滞や血清 Al-p の高値を示した症例で銅沈着が観察
Table 5. Clinical, biochemical feature of the patients with primary biliary cirrhosis (unicteric cases)

\begin{tabular}{|c|c|c|c|c|}
\hline $\begin{array}{l}\text { Case } \\
\text { No. }\end{array}$ & Pruritus & T-chol.* & Al-p.** & $\begin{array}{c}\text { TAB**** } \\
\text { (B-P) }\end{array}$ \\
\hline \multicolumn{5}{|c|}{ asymptomatic PBC } \\
\hline 6 & - & 188 & 8.2 & ND \\
\hline 7 & - & 165 & 8.8 & ND \\
\hline 19 & - & 222 & 13.3 & $7-7$ \\
\hline 20 & - & 118 & 5.7 & $9-13$ \\
\hline \multicolumn{5}{|c|}{ symptomatic $\mathrm{PBC}$} \\
\hline 5 & - & 332 & 47.0 & $16-177$ \\
\hline 13 & $+(2 \mathrm{M})$ & 210 & 29.5 & $11-37$ \\
\hline 14 & $+(3 \mathrm{Y})$ & 327 & 64.0 & $8-63$ \\
\hline 16 & - & 154 & 65.5 & ND \\
\hline 17 & - & 238 & 53.3 & $31-34$ \\
\hline 18 & $+(1 \mathrm{Y} 6 \mathrm{M})$ & 215 & 116.0 & ND \\
\hline
\end{tabular}

$*_{\mathrm{mg}} \mathrm{d} l$ (normal range $140-250$ ) : **K-A.u. : ***TBA, total bile acid, $\mu \mathrm{mol} / l$, B-P, beforepostprandial.

された.

無黄疸例の中で Case 200 overlapping syndrome の 1 例は, 組織学的に乙型肝硬変を伴っているにもかかわ らず銅沈着を認めなかった。このことはPBC としては やはりI期にとどまっており，銅沈着を示すほどの組織 学的変化を来たしていないるのと思われた.

6. PBC 以外の各種胆汁うっ滞における銅染色およ びオルセイン染色結果 (Fig. 10)

PBC 以外の胆汁 万っ滞13例中 6 例 $46.1 \%$ (19標本中 9 標本 $47.3 \%)$ が銅染色およびオルセイン染色陽性であ った.

慢性薬剂起因性肝内胆汁亏っ漁は 4 例之夕 2 回以上の 肝生検を施行し経過観察しえた症例である.4例中 3 例 $75.0 \%$ (10標本中 6 標本 $60.0 \%)$ 飞銅沈着を認めた。長 期にわたる胆汁らっ漁を来たした若年性小葉間胆管形成 不全の 2 兄妹剖検例は銅沈着がいずれも強く観察され た。肝外閉塞性黄疸は 5 例中黄疸が 1 年 1 力月持続した 1 例で銅沈着がみられた。急性訮内胆汁うっ滞は 2 例と る銅沈着はみられなかった。

$\mathrm{PBC}$ 以外の胆汁らっ滞では, 胆汁らっ滞期間が9カ 月以内の 8 例 8 標本では全例銅沈着を認めなかった。一 方, 胆汁5っ滞期間が10カ月以上の症例では，8例中 6 例 $75.0 \%$ (11標本中 9 標本 $81.8 \%$ ) 飞銅沈着がみられ, 


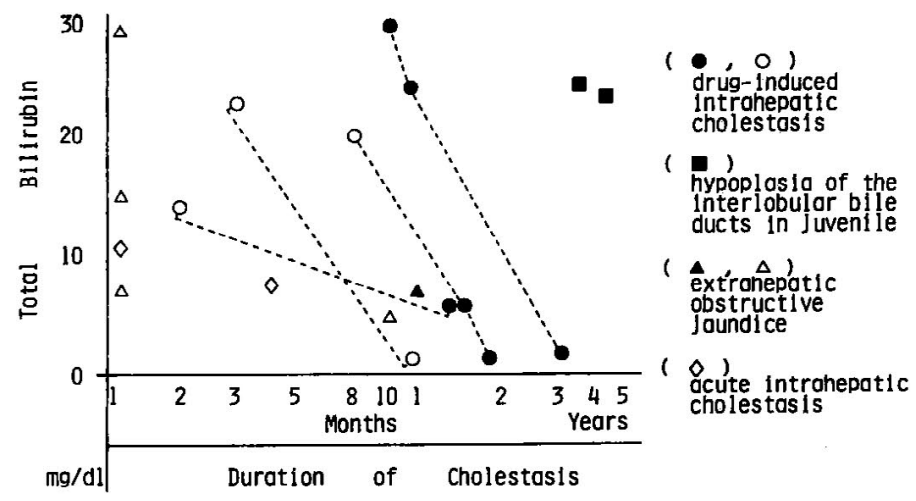

Fig. 10 Relationship between duration of cholestasis and copper-deposits in hepatocytes of patients with other cholestatic liver diseases.

copper-deposits: positive (filled symbols), negative (open symbols). dotted lines indicate the same patients.

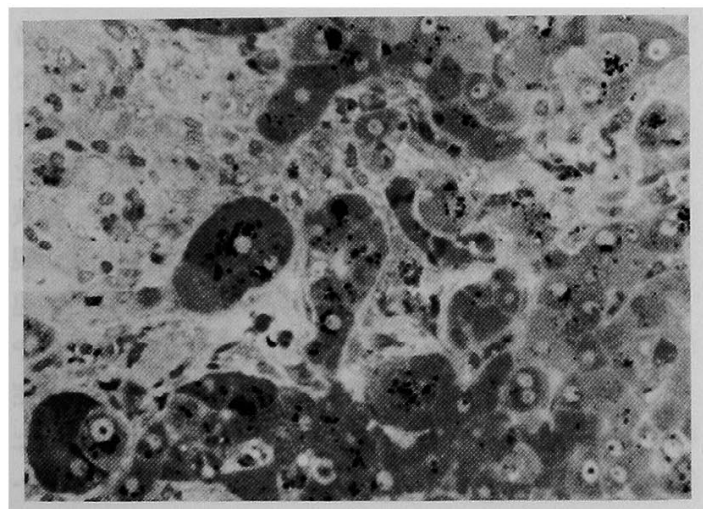

Fig. 11 The similar granular substances are seen in hepatocytes, (toluidine blue stain, $\times 300$ ).

肝組織内銅沈着と胆汁ちっ滞の期間とはよく関連してい た.

\section{7. 透過電䫝による観察結果}

透過電顕による钼察は8例についておこなった. これ らの症例のトルイシンンブルー染色では，肝細胞の多くは 明調䋚胞で少数の暗調細胞がその間に散在していた。 た，小葉周辺部の肝細胞内に主として核周国に0.7〜3.0 $\mu$ 以上の円形・だ円形・不整形の濃青色の顆粒状物質が 多数観察された (Fig. 11).これらの顆粒を透過電顕で 観察すると, 電子密度の極めて高い顆粒が単独で, むる いは電子密度の中等度さらにそれよりも低いるのが混在 してみられた，顆粒をとりまく膜は，個々の顆粒の一 部分で明瞭であったが，不明瞭な部分が多かった（Fig. 12).

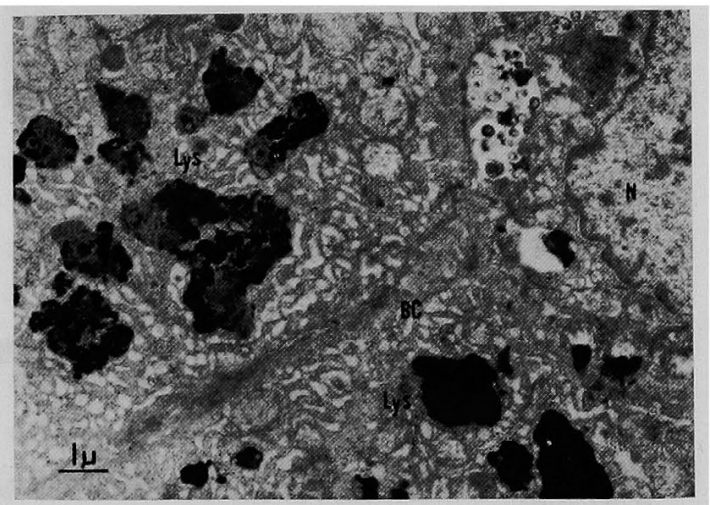

Fig. 12 Secondary lysosomes with various electron density were seen in hepatocytes of periportal area. (PBC, Stage III ; electron micrograph; lead citrate; $\times 10,000$ )

ついで肝細胞内の銅沈着の細胞小器官に対する障害性 を検討するため肝細胞の電䫓的钼察をおこなった８症 例での共通した所見としては滑面小胞体の著明な vesiculation とミェリン様構造物をとり込んだラインゾーム の著しい增加がみられた. このミェリン様構造物は早期 の PBC である無黄疾例の肝細胞内にすでに多数観察さ れた (Fig. 13). その他の肝細胞内小器官の変化として は, 一部の症例で肝細胞膜直下の ectoplasma の肥厚, 粗面小胞体の増加, ミトコンドリアの増加, ミトコンド リア膜の破綻, cristae の減少, matrix の空胞化, microbody の増加などが観察された。 しかし，門脈域周辺 部の肝細胞の変化と中間部〜中心部の肝細胞の変化には 


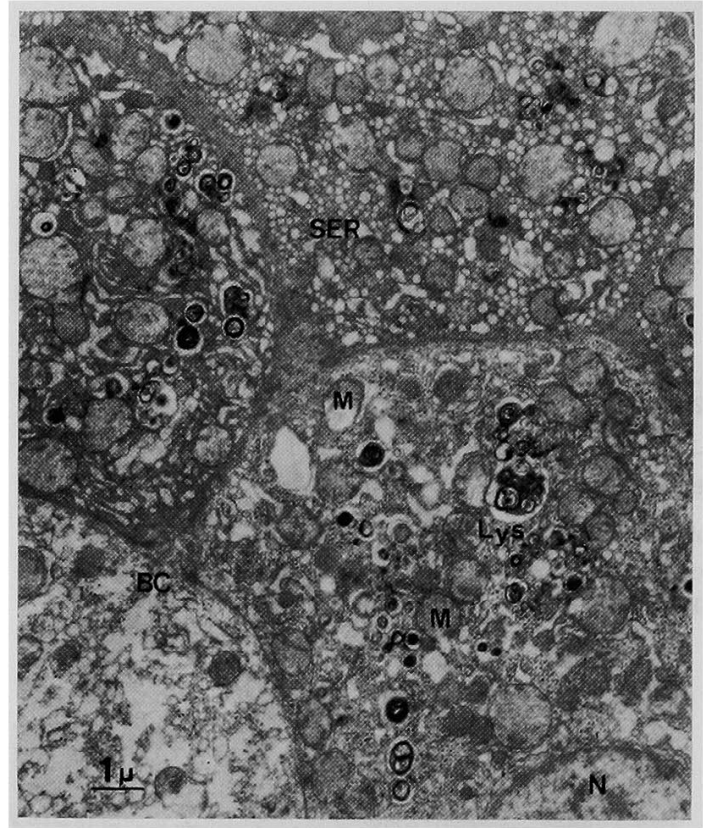

Fig. 13 Many of secondary lysosome containing myelin figures and increased amount of SER were seen in hepatocytes of central area.(PBC, Stage I, electron micrograph; lead citrate, $\times 12,000$ )

差異はみられず，門脈域周园の肝細胞が特に著しく障害 されている像はみられなかった。

\section{IV. 考 案}

各種肝疾患飞淤ける肝組織内の銅の検出法は従来から ロダニン法，ルペアン水素酸法が用いられて来たが，こ れらの光顕的方法にはいくつかの欠点や限界がある.た とえば，(1) 試料の固定・脱水の過程で細胞内の可溶性 分画部分に存在する銅が流出すること ${ }^{23,24)}$ (PBCでは 40〜75\%の銅が可溶性分画部分に存在するといわれてい る7), (2) 銅の組織化学的倹出 が可能となるには, 肝 組織内の銅沈着量が正常の10数倍に達しなければならな いこと ${ }^{25)}$, (3) 銅のみならず, 銀・水銀・金・白金なと (これらは生体内では極く微量しかなく鑑別診断上特に 問題にはならないが）る同様に染色され，笅密には特異 的ではないこと市などがあげられる，従って今回著者が 用いた方法には一定の限界が伴っているが，それらを考 虑しつつ以下の点について考察を加光た.

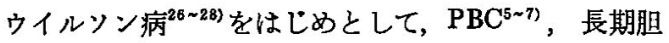
汁らっ滞例 ${ }^{10 \text {-14) }}$ ，慢珄肝炎・肝硬変の一部 ${ }^{5,6,29)}$ など， 各種の肝疾患の肝組織内に銅が沈着することはすでに知
21 巻 9 号 $(1980)$

られているが，近年，PBC に拈いて銅沈着とほぼ一致 して肝組織内にオルセイン染色陽性の顆粒状物質が観察 され， $\mathrm{PBC}$ とAH との鑑別診断に有用であることが 報告されている9． その後，オルセイン陽性顆粒状物質 は各種肝疾患, とりわけ長期胆汁うっ滞でも認めら

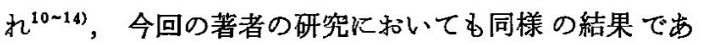
り, PBC とその他の胆汁らっ滞の間では，同物質の出 現頻度に有意の差は認められず，同物質の有無により鑑 別はできないものと思われる. 従ってオルセイン陽性顆 粒状物質は必ずしも PBC に特異的所見とはい之ず, PBC の診断に関しては，特に AMA の陰性例をたは低 力価陽性例では, 臨床所見・検查所見とともに, 組織学 的に CNSDC を証明することが必要である.

銅の定量法を用いた Smallwood ら の の研究により PBC を含めて長期胆汁うっ滞での肝組織内の銅沈着量 は胆汁うっ滞 (ビリルビンを含めた全胆汁成分のうっ 滞）の期間と相関することが明らかにされている. 著者 が用いた定性法においては，PBC 以外の胆汁うっ㯰で は黄㾝が10カ月以上の症例の $81.8 \%$ に肝組織内の銅沈着 が観察され，銅沈着と胆汁うっ滞の期間との間に関連を 認めることか゚できた. しかし，PBC では黄疸例，瑟黄 宣例ともに胆汁成分のうっ滞と強く関連して銅沈着が観 察されたが，黄瘨例では胆汁うっ滞の期間・程度と関連 なく全例に銅沈着がみられ，無黄疸例では皮虚痋痒感や 血清総コレステロール・血清総胆汁酸の高値を示した症 例，即らビリルビン以外の胆汁成分のうっ滞を来たした 症例のみに肝組織内の銅沈着が認められた。一方， asymptomatic PBC では各種胆汁成分のらっ滞はみられず, また銅の沈着も観察されなかった. 後でも述べるが, asymptomatic PBC を含めて無黄疸例の肝組織内銅沈着 に関する研究は治療開始時期とも関連して重要である. しかし，現在までそれに関する報告は少なく，Salaspuro $ら^{8)}$ が肝組織内にオルセイン陽性顆粒状物質を示す症例 で,やはり血清の胆汁酸, Al-p, T-chol などが上昇する ことを報告しているが，無黄疸例での詳しい分析はして いない，本邦では中沼ら ${ }^{12)}$ が asymptomatic PBC で銅 沈着量が正常より増加している1例を報告している.こ れらの点関しての今後の研究が必要であらち.

な拉，無黄㾞例で血清 Al-p 值の中等度ないし高度の 上昇を示した全例に肝組織内の銅沈着が認められ，一方 無黄疾例でも asymptomatic PBC でいずれも血清 Al-p 値が正常かわずかに上昇している程度で，これらの症例 では銅沈着は観察されなかった，胆汁うっ滞に特ける血 
清 Al-p 值の上昇機序については, 胆汁の排泄障害によ る血中への逆流だけでなく，何らかの chemical inducer の停滞が肝での Al-p の合成を促進していると考党られ ているが, 最近 Hatoff $ら^{30)}$ とよりこの chemical inducer が胆汁酸であることが指摘されている。無黄疸例の PBC 飞打いて，血清 Al-p 值の上昇，ビリルビン以外の胆汁 成分らっ滞括よび銅の肝細胞内沈着とが関連して認めら れたことは，Hatoff らの説を臨床面から裏づけるもの として興味ある事実である.

PBC K和ける肝組織内の銅沈着の原因として Hunt $ら^{57}$ は，(1) 腸管からの銅吸収の六進，(2) 胆道閉塞に よる銅のらっ滞, (3) 銅の排泄障害, (4) 銅の代謝障害 などをあげているが，正確な機序は未だ解明されていな い現状である. 著者の研究結果から推察すると，PBC の初期の病変としての肝内胆管の部分的閉塞がをず惹起 され，その結果胆汁成分でも最も量の多い胆汁酸のうっ 㴖，つづいてT-chol，さらにはビリルビンを含む全胆 汁成分のらっ滞が生じ，これらに伴って銅の肝細胞内で の沈着あるいは排泄障害, 即ち Hunt らの述べている (2)，(3)が括こるすのと思われる. PBC とその他の胆汁 らっ滞での銅沈着の機序は汪と九ど同じと考えられ，相 異点としては PBC では胆管の閉塞や胆汁うっ滞が極め て緩慢炕進行するのに比し, 後者では比較的早く進行す るといらことであろち。しかし，胆汁らっ滞以外の対照 例 (肝硬変の 1 例) て肝組織内に 銅沈着を認めたこと は，銅沈着の原因として上記の機序の他に銅の代謝障害 も考虑すべきであるが，その点については将来の問題で あろら。

銅の生体内代謝之肝細胞障害に関して多数の 報告 ${ }^{25}$ ${ }^{29,31 \sim 333}$ がZられ，銅の生体内代謝に関しては今日つぎ

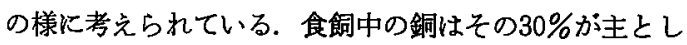
て上部小腸で吸収され，アミノ酸またはアルブミンと結 合し，門脈を経て肝細胞まで運げれ，大部分はせルロプ

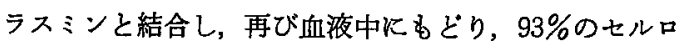
プラスミン一銅と $7 \%$ \%フルブミン, アミノ酸一銅とが 平衡状態にあるといわれている ${ }^{31,322}$. 一方, 肝細胞内に 入った銅の一部は cytosol 内で低分子蛋白質 (metallothionein, copper-chelatin) と結合し，過剩の銅はライン ゾーム内汇とり込をれ，胆汁中に排泄される ${ }^{25)}$.

PBC では cytosol 内の銅が40〜75\%と多いこと”，末 期には閒脈域周辺部の肝細胞内で核周困のライソゾーム 内に多量にみられること”が知られている. このような 肝細胞内の銅が細胞障害珄に働らくことは， $\mathbf{P B C}^{5 \sim 7}$,
ウイルソン病 ${ }^{26 \sim 28)}$, Indian childhood cirrhosis ${ }^{29)}$ などの 疾患に括いて研究されているが，これらの疾患での肝細 胞内銅沈着の局在様式がそれぞれ異なって和り ${ }^{9,27,299}$, 従って銅の肝細胞障害に関してる異なる機序が考党られ ている ${ }^{27,29)}$. PBC に和ける銅の肝細胞障害については 以下の如く考觉られる. (1) 上記の代謝過程で，過剩の 銅が肝細胞内に蓄積してくると,メタロチオネインの合 成が促進され ${ }^{342}$ ，過剩の銅と結合し生体保護の働らきを するが，このメタロチオネインの合成をも上まわる過剩 の銅が肝細胞内蓄積する場合火は，cytosol にびまん 性に分布した銅が細胞障害性に働らく ${ }^{27)}$. (2) 一方, 肝 細胞内の銅をとり込んだラインゾームも生体保護の役割 を果しているが, ライソゾーム内への銅のとり込みが限 界に達すると,ライソゾームの破綻を来たし，銅は再びラ イソゾーム外に出て肝細胞障害性飞働らくほが ${ }^{26)}$ ，ライ ソゾーム酵素の漏出による細胞障害作用が加わり ${ }^{26,95)}$, 一層組織破壊が進展するわのと思われる.

著者の組織化学的方法による光学顕微鏡的検索では, PBC の肝病変の進展とともに肝細胞内の銅の沈着が增 加していたこと, 肝細胞内の銅の局在パターンが細胞質 十核周囲型から核周囲型へ進展したこと, 即ち, 本来毛 細胆管周囲飞存在する一次ラインゾームが銅をとり込 み，肝病変の進展に伴い、細胞中心部一の分布を示したこ となどから，旰細胞内の銅沈着が PBC の肝病変進展の 重要な一因子であることが示唆された．電子顕微鏡所見 からは，vesiculation した滑面小胞体の著しい増加とミ エリン様構造物をとり込んだラインゾームの增加が共通 した所見として観察されたが，その他の細胞小器官の障 害などを含めて, 門脈域周辺部の肝細胞に特に著しい变 化もみられず，銅の肝細胞障害の機序としては前述の(1) の因子が主として働らいている様に思われるが，(1)と(2) の因子がともに働らいていることも否定はできない。な お，肝組織内に銅沈着を認めなかった PBC 4 例中 2 例 (Case 6，7) 飞軽度の線維化 (Stage 11) がみられた が、このことは PBC に和ける肝組織の線維化の原因は 必らずしも銅のみではないことを示している.

PBC 户他の肝疾患飞和ける肝細胞障害・線維化・硬 変化には胆汁酸の役割る重要であることが指摘されてい る ${ }^{36-38)}$ 。教室の成績でる，PBC の早期から空腹時ある い:食飼負荷後の血清総胆汁酸の高值・胆汁酸組成の異 常（ケノデオキシュール酸の増加）および肝細胞での胆 汁酸クリアランスの著しい低下などがみられる゙99 ので， 胆汁酸の肝細胞障害は十分飞考えられる. 銅が腸管に排 
泄される時は胆汁成分と強く結合し，生体保護の役割を 果していることが知られているが 汁酸組成の異常に伴ってどのように変化するかは不明で ある. 著者の成績によると，肝細胞内の銅沈着と各種胆 汁成分のらっ滞との間に強い関連性があると考党られた ので, 胆汁酸が肝病変進展の別な一因子と乙て重要であ るとともに，今後，銅沈着・胆汁酸・肝細胞障害につい ての，特に肝組織材料での相互の研究が必要と思われ た.

PBC 飞括ける肝細胞内の銅およびオルセイン陽性顆 粒状物質の性状を正確に知る目的で分析電子顕徽鏡に上 る元素分析を括こなった，その詳細な分析結果は別に報 告 ${ }^{(2)}$ する予定で岁るが，銅の他に，、グネシウム，才ス ミウム，リン，硫黄，クロール，カリウム，カルシウ ム，鉄，亜鉛などが検出されたままた症例によっては銅 量よりる亜鉛含有量が多い例もみられた。これらの分析 結果から，銅染色とオルセイン染色法に扑ける解離例， 両染色法の量的差異などの検討が可能である.ささらに， 分析電子顕微鏡は肝贜病学の分野飞乱いても，軽元素 ・重金属が蓄積する疾患の病熊の解明に大きな力を発揮 するものと思われる.

PBC の根本的治療が望めない今日，二次的障害 と考 えられる銅の肝細胞内沈着・肝線稚化・硬变化などに対 する治療が疾病の進展を革らせる目的で重要である．最 近, PBC の早期治療の指摘 ${ }^{11}$, D-penicillamine の少量 ( $250 \mathrm{mg} / \mathrm{day})$ 投与に上り副作用を抑克治療奻果を期待す

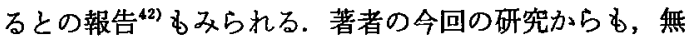
黄疸の時期の PBC でも，皮盧瘙痒感や血清 T-chol, Al-p の高值が持続したり，血清総胆汁酸の高值がみら れる場合には，すでに肝組織内に銅が観察されており， このことは PBC に拈ける銅沈着に対する早期治療の必 要性・治療開始時期の選択に 1 つの指標を与兄るものと 思われた. 早期の PBC での肝細胞内銅の局在は，ライ ソゾームではなくむしろ cytosol 内とあり，細胞障害性 に働らいていると考支られる点からる，早期治療は必要 であるが，さらに asymptomatic PBC の時期から治療 すべきかどうかについては，その時期の肝細胞内銅沈着 に関する定性的・定量的研究はほとんどなく，今後，か かる症例のつみ重赫が重要である. むしその時期にも肝 細胞内銅沈着の著明な增加がみられるとの結諭が得られ れば, asymptomatic PBC の時期から積極的治浩を開 始すべきであろう。

\section{v. まとめ}

PBC の肝病変進展に和ける肝細胞内銅沈着 の 役割, オルセイン染色の診断的有用性などを倹討する目的で， PBC 20例, PBC 以外の胆汁5っ滞13例, 対照群42例, 合計75例飞ついて肝組織標本の銅染色およびオルセイン 染色をおこない，その染色性・染色部位を比較検討し， 特に PBC に和ける銅沈着と胆汁らっ滞の期間・程度・ 治療との関連や銅沈着の肝細胞内局在について検討を加 え，以下の成績を得た.

(1) 全症例の銅染色およびオルセイン染色に的ける染 色性の比較では，銅染色陽性例はいずれもオルセイン染 色陽性で解離例はなかったが，染色程度はオルセイン染 色の方が量的に多くみられた，連続切片での染色部位の 比較では，ロダニン法，ルベアン水素酸法，オルセイン 染色でともに同一小葉内の主として小葉周辺部に，また 多くは同一細胞内の核周囲に顆粒状の染色陽性像が観察 された。

(2) 全症例の銅染色括よびオルセイン染色陽性率は, PBC では20例中16例80\%, PBC 以外の胆汁 万っ滞13例 中 6 例 $46.1 \%$, 対照群は 42 例中 1 例 $2.4 \%$ であった. PBC とその他の胆汁うっ滞の間には有意差はみられず，オル セイン陽性顆粒状物質は PBC に特異的所見々みなすこ とはできなかった。

(3) PBC に打ける肝組織内の銅沈着は asymptomatic PBC では全例飞みとめられず，早期 PBC の一部では 標本の一部に限局し，病期の進展とともに標本全体に 分布し, さらに進行した症例では量的にも多く観察され た。また個々の肝細胞内では病期の進展とともに核周囲 により多く集合する傾向がみられた。

(4) また，PBC の肝組織内の銅沈着は，黄疾例，無 黄疸例ともに胆汁成分の5っ滞之強く関連して観察され たが，黄疸例では全例に，無黄疾例ではビリルビン以外 の胆汁成分のうっ滞，あるいは血清 Al-p 值の上昇と関 連して認められた。

(5) 以上ょり PBC に括ける肝組織内の銅沈着はビリ ルビン以外の胆汁成分の5っ漟を来たす早期から始ま り, 肝病変進展への重要な一因子であることが示唆さ れ，早期治療が必要と思われた。

(6) PBC 以外の胆汁らっ滞では肝組織内の銅沈着は 胆汁らっ滞の期間之相関した.

稿を終えるにあたり御指導ならびに御校閲を睗わった 市田文弘教授に深甚なる謝意を表します。本諭文作製に 
あたり終始貴重な御意見と御指導をいただきました富山 医科薬科大学医学部第三内科佐么木博教授に深謝致しま す. また分析暼子顕微鏡は東京医科歯科大学難治疾患研 究所超微構造部水平敏知教授にお願い致しました。ここ に厚く御礼申し上げます。さらに，本研究に御協力いた たいた教室の上村朝輝諈師をはしめとする諸先生および 本多紀元技官に感謝致します。

本論文の要旨は第15回日本肝臓学会総会(昭和54年 6 月29日，大阪市）にて発表した。

\section{文献}

1) MacMahon, H.E.: Biliary xanthomatosis (Xanthomatous biliary cirrhosis). Am. J. Pathol., 24: 527, 1948.

2) Ahrens, E.H. et al.: Primary biliary cirrhosis. Medicine, 29: 299, 1950.

3) 佐々木博: 胆汁性肝硬変, 新内科学大系, 第22 巻 B, 中山書店, 東京, 1977 , p. 175.

4) Rubin, E. et al.: Primary biliary cirrhosischronic non-suppurative destructive cholangitis. An. J. Pathol., 46: 387, 1965.

5) Hunt, A.H. et al.: Relation between cirrhosis and trace metal content of liver-with special reference to primary biliary cirrhosis and copper. Br. Med. J., 2: 1498, 1963.

6) Smallwood, R.A. et al.: Liver-copper levels in liver disease-studies using neutron activation analysis. Lancet, 2: 1310, 1968.

7) Owen, C.A. et al.: Hepatic subcellular distribution of copper in primary biliary cirrhosis. Mayo Clin. Proc., 52: 73, 1977.

8) Salaspuro, M.P. et al.: Clinical correlations and significance of orcein-positivity in chronic active hepatitis and primary biliary cirrhosis. Ann. Clin. Res., 8: 206, 1976.

9) Sipponen, P. et al.: Orcein positive hepatocellular material in histological diagnosis of primary biliary cirrhosis. Ann. Clin. Res., 7: $273,1975$.

10) Sipponen, P.: Orcein positive hepatocellular material in long-standing biliary diseases-I. Histochemical characteristics. Scand. J. Gastroenterol., 11 : 545, 1976.
11) Sipponen, P.: Orcein positive hepatocellular material in long-standing biliary disease-II. Ultrastructural studies. ibid., 11 : 553, 1976.

12) Salaspuro, M.P. \& Sipponen, P.: Demonstration of an intracellular copper-binding protein by orcein staining in long-standing cholestatic liver diseases. Gut, 17: 787, 1976.

13）中沼安二, 太田五六：各種肝疾患の肝細胞内に 出現する顆粒状オルセイン陽性物質と肝組織内 銅量. 日消会誌, $75: 1190,1978$.

14) Salaspuro, M.P. et al.: The occurrence of orcein-positive hepatocellular material in various liver diseases. Scand. J. Gastroenterol., 11 : $677,1976$.

15) Scheuer, P.J.: "Liver biopsy interpretation", 2nd ed., Bailliere and Tindal, London, 1973.

16）市田文弘：原発性胆汁性肝硬变とその周辺, 第 61 回 日本消化器病学会 総会特 別講演, 日消会 誌, $72: 1428,1975$.

17) Popper, H.: Morphological and immunological studies on chronic aggressive hepatitis and primary biliary cirrhosis, (in) "Immunology of the liver", ed. Smith, M. and Williams, R., William Heinemann Medical Books Ltd., London, 1971, p. 17.

18）市田文弘他：慢性肝内胆汁うっ滞症とその周辺 一サルファ剂によると思われる慢性薬剂起因性 肝内胆汁うっ滞の 2 症例を中心に。日本臨牀， $30: 1875,1972$.

19）佐藤英司他：サルファ剂によると思われる低ガ ンマグロブリン血症を伴った慢性薬剤起因性肝 内胆汁らっ滞症の 1 例. 日消会誌, $72: 1549$, 1975.

20）市田文弘 他：肝内胆汁らっ滞症と乞。 周辺一 Hypoplasia of the interlobular bile ducts in juvenile の提唱. 最新医学, $24: 78,1969$.

21) 佐野 豊: 組織学研究法, 南山堂, 東京, 1979 , p. 623.

22) Sikata, T. et al.: Staining methods of Australia antigen in paraffin section-detection of cytoplasmic inclusion bodies. Jap. J. Exp. Med., 44: $25,1974$.

23）水平敏知 and Russ, J.C. : 分析電子顕微鏡，日 
本メディカルセンター出版部, 東京, 1978 .

24) Mizuhira, V.: Elemental analysis of biological specimen by electron probe X-ray microanalysis, (in) "Pure and applied chemistry", Pergamon Press, Oxford, 1979.

25) Bloomer, L.C. \& Lee, G.R.: Normal hepatic copper metabolism, (in) "Metals and the liver", ed. Powell, L.W., Marcel Dekker, New York and Basel, 1978, p. 179.

26) Goldfischer, S.: The localization of copper in the pericanalicular granules (lysosomes) of liver in Wilson's disease (hepatolenticular degeneration). Am. J. Pathol., 46: 977, 1965.

27) Goldfischer, S. \& Sternlieb, I.: Changes in the distribution of hepatic copper in relation to the progression of Wilson's disease (hepatolenticular degeneration). Am. J. Pathol., 53: 883, 1968.

28) Sternlieb, I.: The development of cirrhosis in Wilson's disease. Clin. Gastroenterol., 4: 367, 1975.

29) Popper, H. et al.: Cytoplasmic copper and its toxic effects-studies in Indian childhood cirrhosis. Lancet, 1: 1205, 1979.

30) Hatoff, D.E. \& Hardison, W.G.M.: Induced synthesis of alkaline phosphatase by bile acids in rat liver cell culture. Gastroenterology, 77 : 1062, 1979.

31) Dowdy, R.P.: Copper metabolism. Am. J. Clin. Nutr., 22: 887, 1969.

32) Evans, G.W.: Copper homeostasis in the mammalian system. Physiol. Rev., 53: 535, 1973.

33) Barka, T. et al.: Structural changes of liver cells in copper intoxication. Arch. Pathol., 78 : $331,1964$.

34) Winge, D.R. et al.: Metal-induced formation of metallothionein in rat liver. Arch. Biochem. Biophys., 170: 242, 1975.
35) Novikoff, A.B. \& Holtzman, E.: Cells and organelles, 2nd ed., Holt, Rinehart and Winston, New York, 1976, p. 150.

36) Bloomer, J.R. et al.: Serum bile acids in primary biliary cirrhosis. Arch. Intern. Med., 136: 57, 1976.

37）加藤英夫，入戸野 博：肝障畫に招ける胆酸代 謝異常，小児科 Mook，白木和夫編，金原出 版, 東京, 1979, p. 205.

38）太田五六：PBC 物よびその周辺疾患に括ける 破壊性胆管病変の 対比亡胆管病変 の形態発生 論，第10回犬山シンポジゥム，中外医学社，東 京, 1979, p. 182.

39）沛田文弘他：原発性胆汁性肝硬変の臨床と問題 点. 肝臓病学の進歩, $5: 72,1979$.

40) Frommer, D.: The binding of copper by bile and serum. Clinical Science, 41: 485, 1971.

41) McCullars, G.M. et al.: Pigment binding of copper in human bile. Clin. Chim. Acta, 74: 33, 1977.

42) 仲 紘嗣他：分析電子顕微鏡による原発性胆汁 性肝硬变に和ける肝細胞内の各種重金属・軽元 素の検出, 第16回日本肝缄学会総会 (昭和55年 7 月 5 日, 東京) 発表.

43) Smallwood, R.A.: Other liver diseases associated with increased liver copper concentration, (in) "Metals and the liver", ed. Powell, L.W., Marcel Dekker, New York and Basel, 1978, p. 313.

44) Scott, J. et al.: Low-dose D-penicillamine in primary biliary cirrhosis improves clinical and liver biochemistry and liver copper (Abstruct). Gastroenterology, 76: 1299, 1979.

45) Katono, S.: A comparative study of passive hemagglutination and immunofluorescent methods for detection of serum mitochondrial antibodies in liver diseases. Gastroenterol. Jpn., 15: No. 3 (in press), 1980. 


\title{
Study on copper-deposits and orcein positive granular substances in hepatocytes of patients with primary biliary cirrhosis and other cholestatic liver diseases
}

\begin{abstract}
Hiroji NAKA*
The present study aimed to elucidate the role of copper-deposits playing in progression of primary biliary cirrhosis (PBC) and the usefullness of orcein positive granular substances (OPGS) for differentiation of cholestatic diseases. OPGS were more numerous than the granules stained for copper but were similar in size, shap and the perinuclear distribution in periportal hepatocytes. Copper-deposits and OPGS in hepatocytes were present in 16 of 20 patients with PBC, 6 of 13 patients with other cholestatic liver diseases and 1 of 42 patients with chronic hepatitis or cirrhosis of liver. Copper-deposits in hepatocytes of patients with PBC were increased in amount and localized in periportal and perinuclear areas as progression of the hepatic changes. Copper-deposits were observed in all of icteric cases and in 6 of 10 unicteric cases. These 6 patients were associated with stagnation of the biliary components except bilirubin. It is presumed that (1) the amount of copper-deposits in hepatocytes may develope together with stagnation of the biliary components except bilirubin and may be one of the most important factors of progression of the hepatic changes in PBC, (2) treatment for copper-deposits should be instituted in early stage, and (3) OPGS are not specific for PBC.
\end{abstract}

* The Third Division, Department of Internal Medicine, Faculty of Medicine, Niigata University (Niigata) 